\title{
CONCENTRATION OF CHLORPROMAZINE IN HUMAN BLOOD AND ITS ELIMINATION IN URINE
}

\author{
KINJIRO IWASA, TOSHIO HARA, KAZUYUKI HAYASHI \\ and TATSUJI TOKUI \\ Department of Neuropsychiatry, School of Medicine, \\ Keio University \\ Inokashira Mental Hospital, Tokyo
}

(Received on June 15, 1957)

\section{INTRODUCTION}

Several results concerning the distribution of chlorpromazine are reported, in which after the administration of big dosis of chlorpromazine to animals, the concentrations of the drug were determined. $(1,2,3)$

However, as the amount of chlorpromazine contained in blood is too small to be determined by usual method, it was almost impossible to know the exact amount of chlorpromazine distributed in human body after the administration of therapeutic dosis of the drug. As far as we know, report by Seibert is the only one in which the concentration of chlorpromazine in human-blood after the administration of therapeutic dosis was dealt with.(4)

It is generally claimed that large total amount and long period of administration are necessary to make certain the effect of chlorpromazine for psychotic states. To overcome those disadvantages we adopted the "Strike by big dosis" method in which big dosis of chlorpromazine was given once a day and the doses was increased day by day in short duration with sudden cessation.

\section{METHOD}

Of nine adult schizophrenic patients, five patients were administered chlorpromazine perorally and 4 patients intramuscularly.

On the first day $100 \mathrm{mg}$ of chlorpromazine was administered and the dosis per day is increased by $100 \mathrm{mg}$ daily until the amount of chlorpromazine per day became 600-700 mg. On the sixth or seventh day, the administration was stopped and the following determination on blood and urine were carried out; total and free chlorpromazine in blood, blood pressure, pulse rate, rectal temperature, total number of leucocytes and haemograms. 
Results at 24 hours before and after the administration of chlorpromazine were used as the control.

Whereas chlorpromazine may be excreted into the urine even 24 hours after administration, we also determined, every 24 hours the amount of chlorpromazine in the urine of two other patients for 3 days who had received no chlorpromazine in advance and $600 \mathrm{mg}$ chlorpromazine only once.

Determination of chlorpromazine was done by the method by Dubost and Pascal. ${ }^{(3)}$

\section{RESULTS}

Fig. 1 shows a curve of total chlorpromazine concentration in the blood in the case of "per os" administration (600-700 mg chlorpromazine). The concentration of chlorpromazine in human blcod began to increase 1 hour after peroral administration of the drug. After 3-5 hours the concentration reached its peak (about $2 \mathrm{mg} / \mathrm{l}$ ) and then gradually decreased. 24 hours after administration, the concentration is almost equal to the control and in 36 hours it decreased too low to be determined.

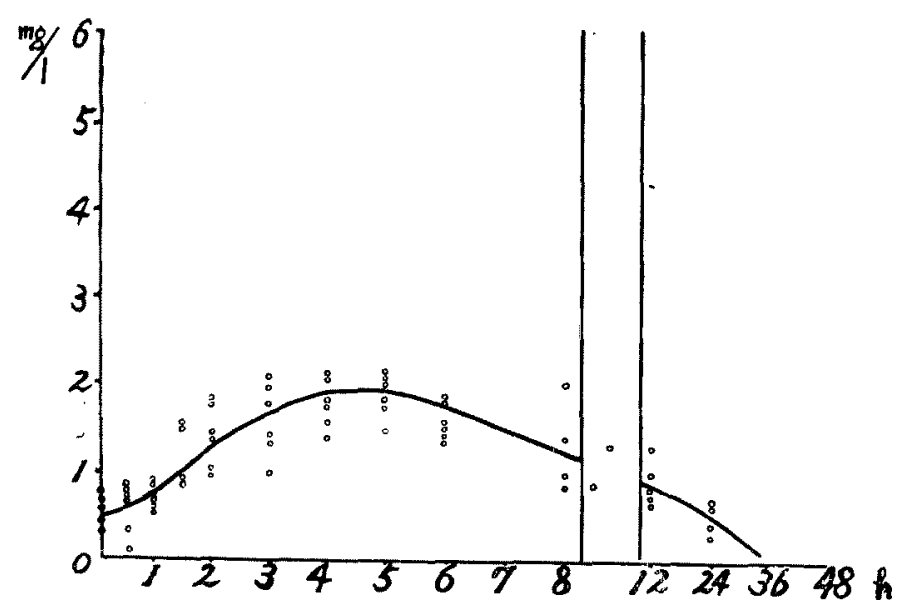

Fig. 1 Concentration of chlorpromazine given "per os". Whole-chlorpromazine in blood $(\mathrm{mg} / \mathrm{l})$.

Curves of chlorpromazine concentration in the blood in the case of intramuscular administration (600 mg chlorpromazine) are shown in Fig. 2. First peak was observed 30 minutes after the administration and then the curve became irregular. And after 48 hours only trace of chlorpromazine was detected. The peak varies with the case, but comparing with Fig. 1 ("per os"), it is much higher $(3.5$ to $5.0 \mathrm{mg} / \mathrm{l})$. In one case it reached $10.0 \mathrm{mg} / 1$ though transiently. 


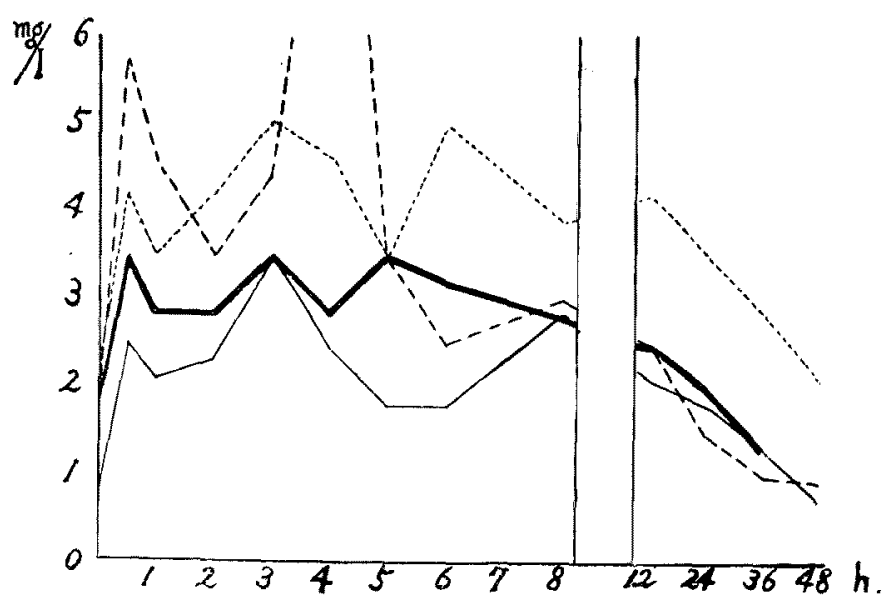

Fig. 2 Concentration of chlorpromazine by intramuscular way. Wholechlorpromazine in blood $(\mathrm{mg} / \mathrm{l})$.

Curves of the two cases, received no chlorpromazine in advance and $600 \mathrm{mg}$ only once, showed no difference to that of ordinary cases mentioned above.

As the amount of free chlorpromazine in the blood gave same value as that of the total chlorpromazine, it is acceptable that only traces of combined chlorpromazine were contained in the blood.

As shown in Table 1, the total amount of chlorpromazine eliminated in the urine in the three days after the "per os" administration was $39.2 \mathrm{mg}$ (free chlorpromazine $12.0 \mathrm{mg}$ ). And in the case of intramuscular administration it was $47.3 \mathrm{mg}$ (free chlorpromazine $15.4 \mathrm{mg}$ ).

Table 1

Quantity of chlorpromazine in urine. Whole-chlorpromazine and free form $(\mathrm{mg})$.

\begin{tabular}{c|c|c|c|c}
\hline \hline Hours & $0 \sim 24 \mathrm{~h}$. & $24 \sim 48$ & $48 \sim 72$ & $\begin{array}{c}\text { Total amount } \\
\text { of 3 Days }\end{array}$ \\
\hline $\begin{array}{c}\text { Administ. Way } \\
\text { “por } \mathrm{mg} \text { per os }\end{array}$ & $\begin{array}{c}24.0 \mathrm{mg} \\
(10.8) \mathrm{mg}\end{array}$ & $\begin{array}{c}9.0 \\
(0.6)\end{array}$ & $\begin{array}{c}6.2 \\
(0.6)\end{array}$ & $\begin{array}{c}39.2 \\
(12)\end{array}$ \\
\hline $\begin{array}{c}600 \mathrm{mg} \\
\text { Intramuscular Inj. }\end{array}$ & $\begin{array}{c}22.5 \\
(8.5)\end{array}$ & $\begin{array}{c}12.0 \\
(4.8)\end{array}$ & $\begin{array}{c}12.8 \\
(2.1)\end{array}$ & $\begin{array}{c}47.3 \\
(15.4)\end{array}$ \\
\hline
\end{tabular}

That the quantities of the total chlorpromazine in the urine in both cases represent $5 \%$ and $7 \%$ of the administrated amount of chlorpromazine respectively, means chlorpromazine is excreted little into urine. It is also to be noted that the amount of combined chlorprcmazine in the urine is two times bigger than that of free chlorpromazine. 
After autoclaving the concentration of chlorpromazine in the blood and the urine was same as that of total chlorpromazine determined by Dubost and Pascal method.

Fall of blood pressure was not parallel with the curve of the chlorpromazine concentration in the blood. It varied in each case and showed irregularity. The sudden decrease of blood pressure was always seen when chlorpromazine present in the blood even though patients were kept in a strictly rest condition. Such sudden falling of blood pressure could be improved by the injection "trans. $\pi$. oxocampher" in a short time.

No significant change could be observed in pulse rate and rectal temperature.

The change in blood cells and the effects on psychotic symptoms will be stated on separate paper.

\section{DISCUSSION}

According to Dubost and Pascal(3) determinations in dogs three hours after the oral administration of chlorpromazine revealed drug plasma levels $6 \mathrm{mg} / \mathrm{l}$, despite the dogs had been taking daily doses of $20 \mathrm{mg}$ per $\mathrm{kg}$ for more than 3 weeks. By the subcutaneous way of the same doses, $3 \mathrm{mg} / 1$ was detected after two hours.

Our patients were given $10-15 \mathrm{mg}$ per $\mathrm{kg}$ chlorpromazine and the maximum value in plasma was $2.3 \mathrm{mg} / \mathrm{l}$ by "per os", $5 \mathrm{mg} / 1$ by intramuscular way (only one case revealed $10 \mathrm{mg} / 1$ transiently. Cf. Fig. 2).

According to Seibert, 90 minutes after the oral administration of $500 \mathrm{mg}$ chlorpromazine the concentration of the drug was less than $10 \mathrm{mg} / \mathrm{l}$ in human blood, despite the fact that the patient had been taking daily doses of $2000 \mathrm{mg}$ for more than a week ${ }^{(4)}$.

And in rabbit's blood only $8 \mathrm{mg} / \mathrm{l}$ chlorpromazine was obtained after giving a high dose i.e., 250-500 mg per $\mathrm{kg}$ (Dubost and Pascal).

From these data it is found the quantities of chlorpromazine in blood is small and the drug remains for 24-48 hours in blood.

Moreover, the total amount of chlorpromazine eliminated into the urine in three days after its administration is only $5-7 \%$ of the total administrated drug.

These data mean that chlorpromazine is decomposed pretty well in animal body. It is also likely that there is no difference in degradation between "per os" and intramuscular administration. But which is to be noted here is the fact that the total amount of chlorpromazine in the blood and its time of penetration into the blood were much higher in the intramuscular method than in the "per os" way. By intramuscular injection, $60 \mathrm{cc}$ of solution was used in one time, 
because the solution for injection in the market was prepared at the rate of $10 \mathrm{mg}$ per $1 \mathrm{cc}$. For this reason absorption from muscle to blood may be retarded to some extent. The first peak of chlorpromazine concentration in plasma 30 minutes after administration is due to the quick transferring of chlorpromazine into the blood through the capillaries.

It has been proved by many workers that chlorpromazine decreases the blood pressure and increases the pulse rate.

We recognized the same phenomenon when chlorpromazine was administrated for the first time even in the case of $50 \mathrm{mg}$ intramuscular injection.

However, in those experiments mentioned above, changes of blood pressure and pulse rate were not always observed, although blood pressure fell down rapidly in some cases during the time when chlorpromazine was detected in the blood.

We guess, this stability of cardiovascular system is caused by the tolerance of the patients to chlorpromazine.

But the rapid fall of blood pressure in some cases warns us that patients should be kept in rest and that the blood pressure and other symptoms must be carefully observed at least 24 hours after administration.

\section{SUMMARY AND CONCLUSION}

9 adult schizophrenic patients received "Strike by big dosis" treatment with chlorpromazine and the concentration of this drug in the blood and the quantity of its elimination into the urine were determined.

1. Total chlorpromazine in the blood in the case of "per os" administration showed the maximum value of about $2 \mathrm{mg} / \mathrm{l}$ between 3 to 5 hours after administration, then it decreased gradually and was nearly equal to the control after 24 hours. In the case of intramuscular administration, the maximum value varied with the case but it was much higher compared with the "per os" way ( 3.5 to $5.0 \mathrm{mg} / \mathrm{l})$.

2. The total amount of total chlorpromazine eliminated into the urine in three days after its administration was only $5-7 \%$ of the administrated drug.

3. In the urine the amount of combined chlorpromazine was two times that of free form but in the blood only traces of combined chlorpromazine were found.

4. With the result mentioned above the following conclusions were drawn: the amount of chlorpromazine in blood after its administration is always small, and drug is decomposed pretty well in the body. 


\section{Acknowledgement}

The authors are grateful to Ass. Prof. E. Hosoya (Department of Pharmacology) and Dr. H. Kondo (Department of Hygine) for their help and advice.

Chlorpromazine used in this study were presented by Shionogi Co., Ltd. (Wintermin) and Yoshitomi Pharmaceutical Industries, Ltd. (Contomin).

\section{BIBLIOGRAPHY}

1. Berti, T. \& Cima, T.: Distribuzione degli aminoderivati fenotiazinici nell' organismo animale., Arch. inter. Pharmacodynamie, 98, 452, 1954.

2. Besson, S. \& Leder, M.: Le répartition de la chlorpromazine $\left(456^{\circ}\right.$ R. P. ou Largactil) dans le sang et dans les tissues. Etude in ritro., Bull. Soc. Pharm. Nancy, 23, 4, 1954.

3. Dubost, P. \& Pascal, S.: Dosage du Largactil dans les liquides biologiques. Etude du passage dans l'organisme animal., Ann. pharm. Franc., 11, 615, 1953.

4. Moyer, J. H.: The pharmacology of chlorpromazine., Inter. Record of Med. \& G. P. Clinies, 301, May, 1955. 